\title{
EFFECT OF DIFFERENT PLANT ARRANGEMENTS ON MAIZE MORPHOLOGY AND FORAGE QUALITY
}

\author{
JANA JIRMANOVÁ, PAVEL FUKSA*, JOSEF HAKL, VÁCLAV BRANT, \\ JAROMÍR ŠANTRŮČEK
}

Czech University of Life Sciences Prague, Czech Republic

JIRMANOVÁ, J. - FUKSA, P. - HAKL, J. - BRANT, V. - ŠANTRU゚ČEK, J.: Effect of different plant arrangements on maize morphology and forage quality. Agriculture (Pol'nohospodárstvo), vol. 62, 2016, no. 2, pp. 62-71.

\begin{abstract}
A study was carried out in Central Bohemia to understand the effect of row spacing and stand density on plant morphology, productivity and quality of silage maize in two row spacing treatments $(0.70 \mathrm{~m}$ and $0.35 \mathrm{~m})$ at two stand densities $(92,000 \mathrm{plants} / \mathrm{ha}$ and $110,000 \mathrm{plants} / \mathrm{ha})$. The results of the study showed that row spacing and stand density had no effect on plant height or weight; however, significantly higher ear ratio and dry matter content was found in narrow rows at 110,000 plants/ha. It was observed that plant morphology was affected more by the interaction between row spacing and stand density than by a single effect of tested factors. Significantly higher dry matter yield was recorded at higher stand density, but there was no row spacing $\times$ stand density interaction. Row spacing had no impact on the whole plant neutral detergent fiber (NDF) content, crude protein of stover and starch content of ear, while narrow rows resulted in almost significantly higher stover NDF content. Our results suggest that narrow rows could be advantageous for maize morphology and quality in cases where higher stand density is applied.
\end{abstract}

Key words: row spacing, stand density, plant height, plant parts, NDF, crude protein, starch content

Maize plant arrangement is one of the most important management tools to improve solar radiation interception and can be done through changes in plant density, row spacing and distribution of plants in the row with the aim of optimizing its use and maximizing the yield (Modolo et al. 2010). Generally, plant arrangement is a function of used stand density per area unit and plant spacing in this area.

The effect of plant density on the yield is usually significant and generally predictable (Stone $e t$ al. 2000). Silage or grain yield increases gradually with increasing plant densities up to plateau, and then the yield decreases. Gözübenli et al. (2004) found the highest yield at a density of 90,000 plants/ha, and
Çarpici et al. (2010) found the same effect at density of 180,000 plants/ha. Regarding plant morphology, minimal or no effect of stand density was recorded on plant height, leaf number and the number of ears per plant (Turgut et al. 2005).

However, increasing the plant density reduced the nutritive quality of forage maize. As plant density increases, crude protein (CP) and dry matter digestibility (DMD) decrease, but acid detergent fiber (ADF) and neutral detergent fiber (NDF) increase (Widdicombe \& Thelen 2002). The reduction in forage quality with increasing plant density is attributed to the decline in leaf to stalk ratio, as well as reduced ear to whole plant ratio (Baghdadi et al.

Ing. Jana Jirmanová, Ing. Pavel Fuksa, PhD. ("Corresponding author), doc. Ing. Josef Hakl, PhD., prof. Ing. Jaromír Šantrůček, CSc., Czech University of Life Sciences Prague, Faculty of Agrobiology, Food and Natural Resource, Department of Forage Crops and Grassland Management, Kamýcká 129, 165 21, Prague 6-Suchdol, Czech Republic. E-mail: fuksa@af.czu.cz

doc. Ing. Václav Brant, PhD., Czech University of Life Sciences Prague, Faculty of Agrobiology, Food and Natural Resource, Department of Agroecology and Biometeorology, Kamýcká 129, 165 21, Prague 6-Suchdol, Czech Republic 
2012). However, Çarpici et al. (2010) recorded no effects of stand density on leaf percentage, $\mathrm{CP}$ and NDF.

The reported influence of row spacing on maize yield and quality has been inconsistent. Alternative spatial arrangement should theoretically decrease plant-to-plant competition, alleviate crop crowding stress and improve yields (Robles et al. 2012). Reduction in row spacing provides a more uniform distribution among plants, which can increase yield (Strieder et al. 2008). The benefits of narrow row spacing can depend on the kind of crop management system (Strieder et al. 2008), the hybrid used (Baron et al. 2006) and the environmental conditions (Balkcom et al. 2011).

Regarding forage quality, the narrow row production system neither had any impact on the nutritive value of maize, such as DMD, ADF, NDF and CP (Widdicombe \& Thelen 2002), nor on the concentration of starch, simple sugars and digestibility of NDF (Beres et al. 2008). However, Baron et al. (2006) and Skonieski et al. (2014) recorded higher content of $\mathrm{CP}$ for conventional rows compared with the narrow rows.

The variable results of the effect of row spacing suggested that this effect is strongly related to the environment, as well as other crop management tools including plant density. Experiments with alternative spatial arrangement have been conducted predominantly in the USA (Widdicombe \& Thelen 2002; Balkcom et al. 2011), Argentina (Barbieri et al. 2012), Brazil (Strieder et al. 2008; Modolo et al. 2010), Turkey (Turgut et al. 2005; Çarpici et al. 2010; Gözübenli 2010), as well as in Pakistan (Maqbool et al. 2006), Iran (Ramezani et al. 2011) and New Zealand (Stone et al. 2000). For Central Europe region, there is a lack of results for alternative spatial arrangement, especially for maize forage quality.

The aim of this study was to investigate the effect of row spacing on plant morphology, productivity and nutritive value of silage maize in the Czech Republic. In view of the parallel effect of plant density on evaluated traits, two levels of stand density were used in this study.

\section{MATERIAL AND METHODS}

The field experiments were conducted at two locations of Central Bohemia, Czech Republic, in the growing season of the year 2013.

Experiment A: Plot experiment was established on the experimental field of the Faculty of Agrobiology, Food and Natural Resources at the Czech University of Life Sciences Prague $\left(50^{\circ} 7^{\prime} 39^{\prime \prime} \mathrm{N}\right.$, $14^{\circ} 22^{\prime} 19^{\prime \prime}$ E, $286 \mathrm{~m}$ a.s.1.). The long-term annual air temperature at the experimental field is $9.1{ }^{\circ} \mathrm{C}$ and the total sum of precipitation is $495 \mathrm{~mm}$. Daily sums

$\mathrm{T}$ a

Monthly sums of precipitation and mean air temperature for the period from 1.4.2013 to 30.9.2013 (Experiment A - Prague, Experiment B - Budihostice)

\begin{tabular}{|l|c|c|c|c|}
\hline \multirow{2}{*}{} & \multicolumn{2}{|c|}{ Experiment A } & \multicolumn{2}{c|}{ Experiment B } \\
\cline { 2 - 5 } & Air temperature & Precipitation & Air temperature & Precipitation \\
\cline { 2 - 5 } & {$\left[{ }^{\circ} \mathrm{C}\right]$} & {$[\mathrm{mm}]$} & {$\left[{ }^{\circ} \mathrm{C}\right]$} & {$[\mathrm{mm}]$} \\
\hline April & 9.6 & 25.3 & 9.3 & 24.3 \\
May & 12.7 & 106.5 & 12.8 & 104.7 \\
June & 16.8 & 173.4 & 16.6 & 127.6 \\
July & 20.6 & 54.3 & 20.0 & 44.7 \\
August & 18.5 & 89.5 & 18.4 & 89.7 \\
September & 13.1 & 37.5 & 13.3 & 58.5 \\
Vegetation period & 15.3 & 486.5 & 15.1 & 449.5 \\
\hline
\end{tabular}


of precipitation and mean air temperature for the vegetation period are shown in Figure 1. Monthly sums of precipitation and mean air temperature are presented in Table 1. The soil was Haplic Chernozem. Soil types were determined according to the World Reference Base (IUSS Working Group WRB 2014).

The tested stand densities of maize were 92,000 and 110,000 plants/ha at row spacing treatments 0.70 and $0.35 \mathrm{~m}$, respectively. The experiment was designed at Latin square with four replications of the main plot. Plot size was $2.8 \times 5 \mathrm{~m}$ with four and eight rows for conventional and narrow rows, respectively. Maize (hybrid Kuxxar, FAO 300) was hand-sown to a depth of $4 \mathrm{~cm}$ on 29 April 2013.

At the experimental site, the silage maize had been continuously cultivated since 2004 under conventional tillage practices. Fertilisers were applied prior to seeding at rates of $120 \mathrm{~kg} \mathrm{~N} / \mathrm{ha}$ (ammonium sulphate), $45 \mathrm{~kg} \mathrm{P} / \mathrm{ha}$ (superphosphate) and $120 \mathrm{~kg} \mathrm{~K} / \mathrm{ha}$ (potassium chloride). Weed control was ensured using post-emergent herbicide Laudis (100 g tembotrione/ha and $50 \mathrm{~g}$ isoxadifen-ethyl $/ \mathrm{ha})$. Two $(0.70 \mathrm{~m}$ row spacing) or four $(0.35 \mathrm{~m}$ row spacing) rows at the centre of each plot were manually harvested at optimal silage maturity on 11 September 2013.

Experiment B: An additional experiment verifying the influence of row spacing in field conditions was established in the experimental area situated near village Budihostice $\left(50^{\circ} 19^{\prime} 7^{\prime \prime} \mathrm{N}, 14^{\circ} 15^{\prime} 42^{\prime \prime}\right.$ E, $233 \mathrm{~m}$ a.s.1.). In this area, the long-term annual air temperature is $9.6^{\circ} \mathrm{C}$ and the total sum of precipitation is $582 \mathrm{~mm}$. Daily sums of precipitation and mean air temperature are presented in Figure 1 , and monthly averages are summarized in Table 1. According to the World Reference Base (IUSS

Experiment A

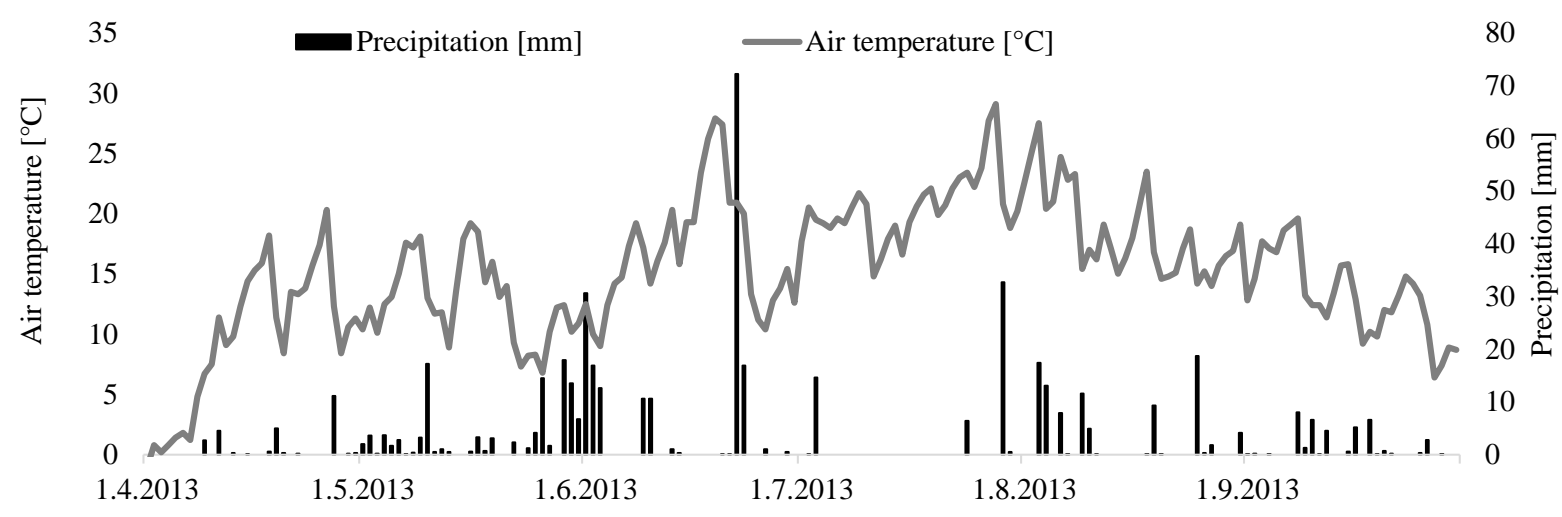

Experiment B

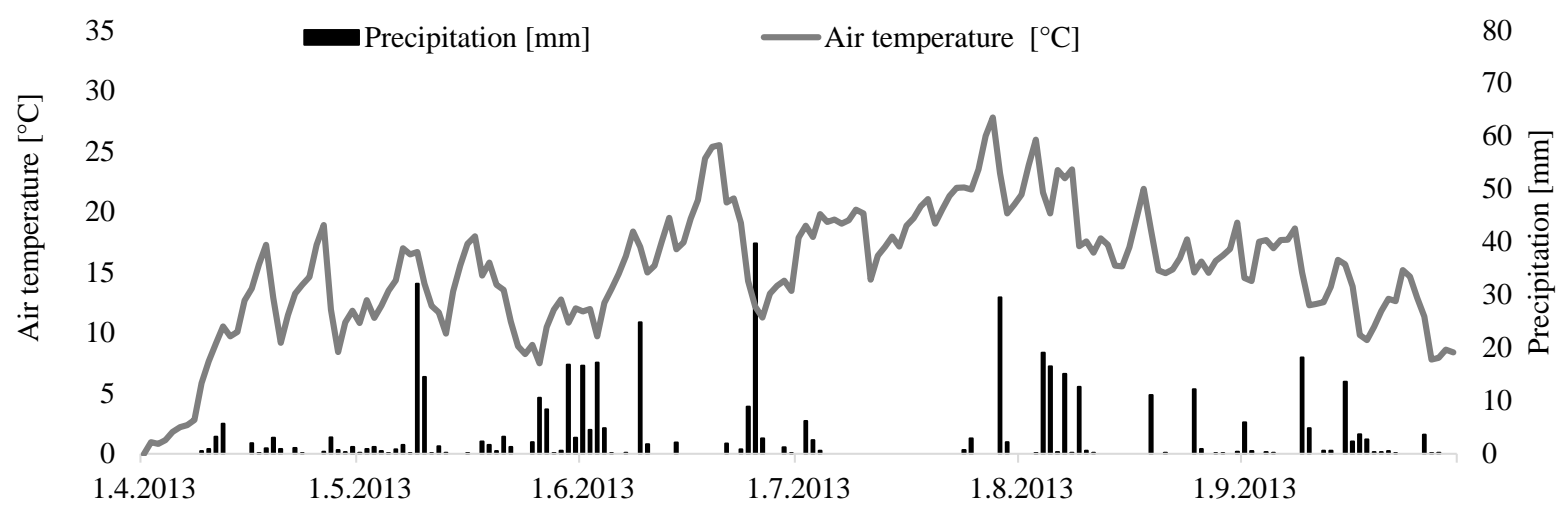

Figure 2. Daily sums of precipitation and mean air temperature for the period from 1.4.2013 to 30.9.2013 (Experiment A - Prague, Experiment B - Budihostice) 
Working Group WRB 2014), the soil was Haplic Chernozem.

Row spacing treatments were 0.75 and $0.45 \mathrm{~m}$, with the average number of plants per hectare being 89,000 plants/ha and 88,000 plants/ha, respectively. Hybrid PR38N86 (FAO 290) was sown on 19 April
2013 by six-row seeder Kverneland Accord Optima HD. Experimental plot size was 1 ha for each treatment and sampling was realised within each plot. The maize followed the winter wheat (Triticum aestivum L.). Tillage practices, fertilisation and weed control were identical with Experiment A. The

$\mathrm{T}$ a

Effect of row spacing (RS) and stand density (SD) on plant height, plant weight, proportion of plant parts and dry matter yield

(Experiment A - Prague, Experiment B - Budihostice)

\begin{tabular}{|c|c|c|c|c|c|c|c|c|}
\hline \multirow{2}{*}{ Site } & \multirow{2}{*}{$\begin{array}{c}\text { Row } \\
\text { spacing } \\
{[\mathrm{m}]}\end{array}$} & \multirow{2}{*}{$\begin{array}{c}\text { Stand } \\
\text { density } \\
\text { [plants/ha] }\end{array}$} & \multirow{2}{*}{$\begin{array}{l}\text { Plant } \\
\text { height } \\
{[\mathrm{m}]}\end{array}$} & \multirow{2}{*}{$\begin{array}{c}\text { Plant } \\
\text { weight } \\
{[\mathrm{g}]}\end{array}$} & Leaf & Stalk & Ear & \multirow{2}{*}{$\begin{array}{l}\text { Yield } \\
\text { [t/ha] }\end{array}$} \\
\hline & & & & & \multicolumn{3}{|c|}{$[\mathrm{g} / \mathrm{kg}]$} & \\
\hline \multirow{7}{*}{ Experiment A } & \multirow{2}{*}{0.35} & 92,000 & 2.37 & 270 & 124 & 286 & $590^{\mathrm{ab}}$ & 20.0 \\
\hline & & 110,000 & 2.37 & 248 & 133 & 250 & $616^{\mathrm{a}}$ & 22.7 \\
\hline & \multirow{2}{*}{0.70} & 92,000 & 2.39 & 245 & 121 & 285 & $594^{\mathrm{ab}}$ & 19.2 \\
\hline & & 110,000 & 2.43 & 296 & 130 & 294 & $576^{\mathrm{b}}$ & 21.5 \\
\hline & \multirow{3}{*}{$P$} & $\mathrm{RS}$ & 0.709 & 0.526 & 0.633 & 0.090 & 0.089 & 0.281 \\
\hline & & SD & 0.817 & 0.446 & 0.236 & 0.270 & 0.660 & 0.013 \\
\hline & & $\mathrm{RS} \times \mathrm{SD}$ & 0.819 & 0.066 & 0.994 & 0.081 & 0.041 & 0.805 \\
\hline \multirow{3}{*}{ Experiment B } & 0.45 & 88,000 & 3.14 & 289 & 113 & 287 & 599 & 24.0 \\
\hline & 0.75 & 89,000 & 3.11 & 281 & 117 & 279 & 603 & 25.3 \\
\hline & $P$ & - & 0.724 & 0.602 & 0.315 & 0.381 & 0.714 & 0.223 \\
\hline
\end{tabular}

$P=$ probability; different letters indicate statistical differences for Tukey $H S D(\alpha=0.05)$

$\mathrm{T}$ a

Effect of row spacing (RS) and stand density (SD) on the dry matter content of whole plant (DMC $\left.\mathrm{wP}_{\mathrm{wP}}\right)$, neutral detergent fiber of whole plant $\left(\mathrm{NDF}_{\mathrm{wP}}\right)$, neutral detergent fiber of stover $\left(\mathrm{NDF}_{\mathrm{S}}\right)$, crude protein of stover $\left(\mathrm{CP}_{\mathrm{S}}\right)$ and starch of ear

(Experiment A - Prague, Experiment B - Budihostice)

\begin{tabular}{|c|c|c|c|c|c|c|c|}
\hline \multirow{2}{*}{ Site } & \multirow{2}{*}{$\begin{array}{c}\text { Row } \\
\text { spacing } \\
{[\mathrm{m}]}\end{array}$} & \multirow{2}{*}{$\begin{array}{c}\text { Stand } \\
\text { density } \\
\text { [plants/ha] }\end{array}$} & $\mathrm{DMC}_{\mathrm{WP}}$ & $\mathrm{NDF}_{\mathrm{WP}}$ & $\mathrm{NDF}_{\mathrm{s}}$ & $\mathrm{CP}_{\mathrm{S}}$ & Starch $_{\text {EAR }}$ \\
\hline & & & \multicolumn{5}{|c|}{$[\mathrm{g} / \mathrm{kg}]$} \\
\hline \multirow{7}{*}{ Experiment A } & \multirow{2}{*}{0.35} & 92,000 & $318^{\mathrm{a}}$ & 410 & 604 & 51 & 467 \\
\hline & & 110,000 & $347^{b}$ & 405 & 616 & 45 & 463 \\
\hline & \multirow{2}{*}{0.70} & 92,000 & $327^{\mathrm{ab}}$ & 416 & 595 & 45 & 470 \\
\hline & & 110,000 & $333^{\mathrm{ab}}$ & 411 & 571 & 46 & 472 \\
\hline & \multirow{3}{*}{$P$} & $\mathrm{RS}$ & 0.663 & 0.484 & 0.099 & 0.663 & 0.817 \\
\hline & & SD & 0.015 & 0.563 & 0.700 & 0.706 & 0.974 \\
\hline & & $\mathrm{RS} \times \mathrm{SD}$ & 0.085 & 0.923 & 0.256 & 0.530 & 0.913 \\
\hline \multirow{3}{*}{ Experiment B } & 0.45 & 88,000 & 327 & 436 & 663 & 69 & 551 \\
\hline & 0.75 & 89,000 & 316 & 444 & 687 & 63 & 552 \\
\hline & $P$ & - & 0.264 & 0.375 & 0.136 & 0.406 & 0.947 \\
\hline
\end{tabular}

$P=$ probability; different letters indicate statistical differences for Tukey $H S D(\alpha=0.05)$ 
maize was harvested at optimal silage maturity on 10 September 2013. The yield was assessed using the average plant weight (evaluated twenty plants per treatment) and the number of plants per hectare.

Harvest measurements and plant morphology: The measurement of plant height and sampling of above-ground biomass were realized during harvest time. In Experiment A, plant height was measured at 20 plants in the centre of two rows of each plot from the soil surface to the tip of tassel (m), and four plants were randomly selected (from each plot) to determine dry matter content (DMC) and forage quality characteristics. In Experiment B, $4 \times 10$ plants were measured for height and $4 \times 4$ plants from each tested spatial arrangements were selected for the following analyses. The sampled fresh plants were divided into ear, leaf and stalk, and dried at $60^{\circ} \mathrm{C}$ in a forced-air dryer for calculation of their weight percentage ratio.

Forage quality: Dried samples of plant parts from each plot were ground in a mill on sieve with $1 \mathrm{~mm}$ mesh size. Mixed samples of leaves and stalks (i.e. the stover) were analysed for crude protein $(\mathrm{CP}, \mathrm{N}$ $x$ 6.25) by Dumas combustion method (Dumatherm $\mathrm{N}$ analyser). Amylase-treated neutral detergent fibre (2002.04) in stover and starch in ear by the amylase method (920.40) were assessed according to Association of Official Analytical Chemists (2005). In the ear, the NDF content $283 \mathrm{~g} / \mathrm{kg}$ was considered to be constant value. The NDF of whole plant was calculated from ear ratio and NDF content in the stover.

Statistical analysis: The data of maize yield, plant morphology and forage quality were statistically evaluated by using two- and one-way analysis of variance in Experiments A and B, respectively. All analyses were performed using Statistica 12 (2013) followed by Tukey post-hoc test $(\alpha=0.05)$. Ordination biplot of principal component analysis (PCA) was created in CanoDraw (Microcomputer Power, Ithaca, NY) for graphical visualization of the relationship between maize morphology and quality (dependent variables), and row spacing and stand density (combination of groups used as supplementary variables). All ordination analyses were

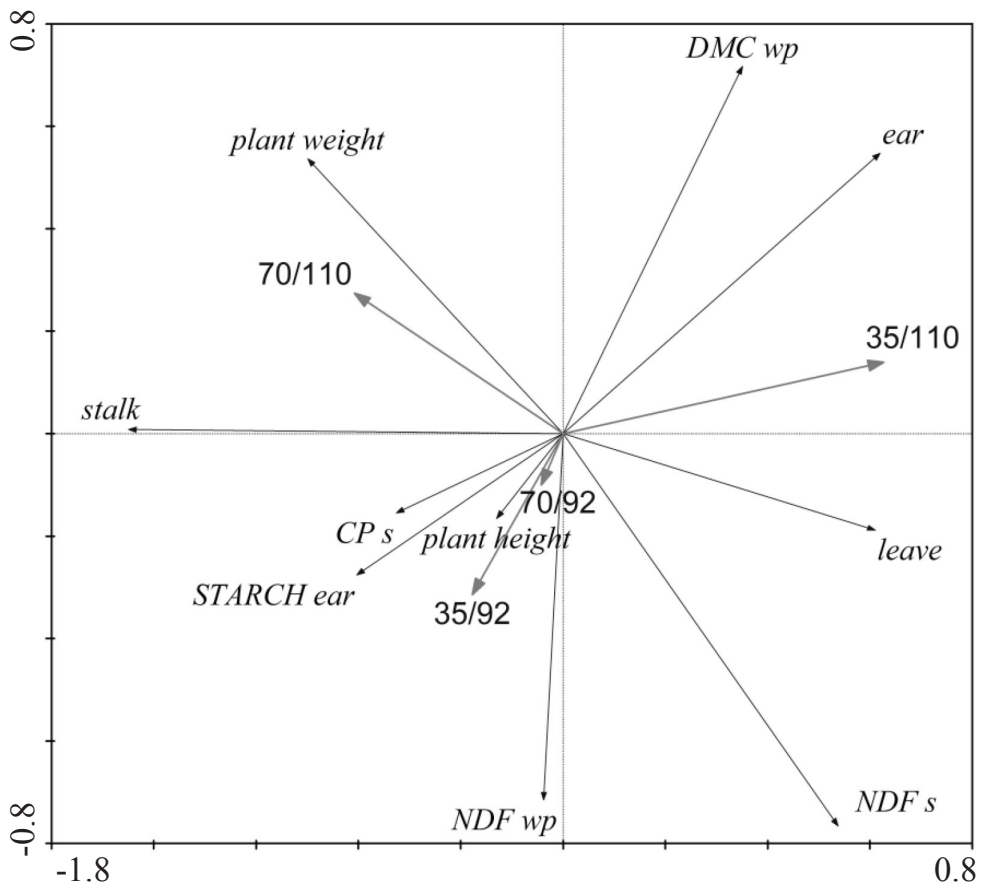

$\mathrm{DMC}_{\mathrm{WP}}-$ dry matter content of whole plant; $\mathrm{NDF}_{\mathrm{WP}}-$ neutral detergent fiber of whole plant; $\mathrm{NDF}_{\mathrm{S}}-$ neutral detergent fiber of stover; $\mathrm{CP}_{\mathrm{S}}$ - crude protein of stover; treatments are described as row spacing $(70$ and $35 \mathrm{~cm}) /$ stand density $(92,000$ and 110,000 plants/ha)

Figure 2. Ordination biplot of PCA shows the relationship between maize plant morphology and forage quality (dependent variables) regarding different row spacing and stand density (supplementary variables), Experiment A - Prague 
performed in CANOCO for Windows 4.5 program (ter Braak \& Šmilauer 2002).

\section{RESULTS}

Maize plant morphology and dry matter yield in relation to row spacing and stand density are summarized in Table 2. In the field Experiment A, the impact of row spacing was almost significant for ear and stalk proportion. Stand density showed significant effect only on the yield. However, the interaction row spacing $\times$ stand density was significant or almost significant for plant weight, stalk and ear proportion. Within $0.35 \mathrm{~m}$ rows, increasing the stand density reduced plant weight and stalk proportion, whereas ear proportion was significantly higher than those in $0.70 \mathrm{~m}$ rows under higher stand density. In the field Experiment B with one level of stand density, any significant difference was found for all evaluated traits in line with lower density in Experiment A.

Differences in DM content and forage quality over different row spacing and stand density are shown in Table 3. In Experiment A, the effect of row spacing was almost significant just for stover NDF content, where higher values were observed within $0.35 \mathrm{~m}$ rows regardless of stand density. Higher stand density tends to increase of DM content but this effect was visible only within $0.35 \mathrm{~m}$ rows where the highest value was observed. In Experiment $\mathrm{B}$, any differences between row widths were not visible at all evaluated traits.

The effect of row spacing and stand density on relationship among maize plant morphology and forage quality in Experiment $\mathrm{A}$ is illustrated in the ordination biplot of PCA (Figure 2). The most important first (horizontal) canonical axis represents the positive correlation between the stalk opposite to ear and leaves proportion; the second (vertical) axis represents the negative relation between DM content and plant NDF. Both axes were strongly affected by the negative relationships between plant weight and stover NDF, and between ear ratio and ear starch concentration. Regarding the external supplementary factors, both treatments with lower stand density were located in the centre of the figure regardless of row spacing. In contrast to this, higher stand density separated treatments according to row spacing: $0.35 \mathrm{~m}$ to right and $0.70 \mathrm{~m}$ to left side (see Figure 2). Narrow rows under higher density were associated with higher ear and leave ratio, as well as DM content and stover NDF. Plant weight and stalk proportion were related to $0.70 \mathrm{~m}$ row spacing.

\section{DISCUSSION}

The presented values of plant morphology and forage quality traits were within the usual ranges published about maize plot experiments (Cox \& Cherney 2001; Millner \& Villaver 2005). Our results showed that the impact of different row maize spacing on morphology and forage quality was not meaningful, similar to the results presented by Widdicombe and Thelen (2002) or Stone et al. (2000). Also, the differences in stand density did not show any significant changes within the given ranges, except for DM content. It must be taken into account that evaluated year 2013 was humid; $98 \%$ and $77 \%$ of long-term annual sum of precipitation was achieved over vegetation period in localities of Experiment A and B, respectively. In 2013, the yield was considerably influenced by the climatic condition of the growing season. In this year, in the Czech Republic, the average yields of silage maize were lower by $19.6 \%$ and $19.1 \%$ in comparison to years 2012 and 2014 according to Czech Statistical Office (2015), respectively. Significant single effect of the year on the yield of grain and silage maize was described by many authors (Çarpici et al. 2010; Novacek et al. 2013), but significant year $\times$ row spacing or year $\times$ stand density interactions were not determined (Barbieri et al. 2012; Novacek et al. 2013).

In spite of a humid experimental year, almost significant interactions between row spacing and stand density were observed. It appeared that the effect of plant spacing on evaluated traits was enhanced due to an increase in the plant population density in the present experiment.

\section{Plant morphology and dry matter yield}

Regarding the plant morphology under higher population density in our experiment, wide rows increased the plant weight and stalk proportion, while the ear ratio was significantly reduced. In spite of 
these changes in proportion, the plant height as well as leaves ratio were relatively stable across all treatments. Reduced ear ratio under increased plant yield was in accordance with the results reported by Çarpici et al. (2010). According to Baghdadi et al. (2012), the reduction in forage quality with an increasing stand density (from 90,000 to 130,000 plants/ha) was attributed to the decline in leaf to stalk ratio, as well as reduced ear to whole plant ratio. On the contrary, Iptas and Acar (2006) did not observe any significant changes in ear proportion between different row spaces; however, changes in stand density was not independent of row spacing in their experiment. Millner and Villaver (2005) or Ramezani et al. (2011) did not find any significant effect of stand density on plant part proportion and plant weight.

Plant height is an important component that helps in the determination of growth attained during the growing period (Zamir et al. 2011). In our experiment, this trait was not affected by stand density or row spacing arrangement. This is in agreement with Çarpici et al. (2010) or Ramezani et al. (2011) for different stand densities and with Turgut et al. (2005) for various row spacings. However, some effects on plant height were previously described by Gözübenli (2010) who reported significantly higher plant height in narrow rows compared with conventional rows $(2.07$ vs. $2.00 \mathrm{~m})$ on average of two years, while Ramezani et al. (2011) observed the opposite effect ( 2.10 vs. $2.23 \mathrm{~m}$ ).

Our result suggests an increase in ear ratio under higher density level in narrow rows, which corresponds with Modolo et al. (2010), who reported some tendency of narrow rows to produce higher grain yield. It is possible to assume that ear ratio reduction together with increase in the stalk proportion could be observed, where row spacing, stand density or their interaction increase the plant weight.

Significantly higher dry matter yield at higher plant stand density corresponded with the results of many authors. Across two years, Çarpici et al. (2010) published a significantly higher dry matter yield $(21.26 \mathrm{t} / \mathrm{ha})$ at 180,000 plants/ha in comparison to 60,000 and 100,000 plants/ha (18.72 and $19.45 \mathrm{t} / \mathrm{ha}$, respectively). Baron et al. (2006) found greater impact of population density on yield increase $(+6.4 \%)$ than row spacing and hybrid choice during two-year experiments. In Experiment A, the yield $(4.2 \%$ at 92,000 plant $/$ ha and $5.6 \%$ at 110,000 plant/ha) increased when the row spacing was narrowed from 0.70 to $0.35 \mathrm{~m}$. Comparable increase of yield (5.4\%) for narrow rows was presented by Widdicombe and Thelen (2002). Similar to Baron et al. (2006), no row spacing $\times$ stand density interaction was found in our experiment as well. In Experiment $\mathrm{B}$, higher yield in narrow rows was not observed, which corresponded with Skoniesky et al. (2014). These results highlighted that hybrids evaluated in two experimental localities did not show the same effect in similar row spacing, as was published by Turgut et al. (2005).

\section{Forage quality}

Maize DM content parameter is closely connected with harvest timing (Lynch et al. 2012). Non-significant differences in maize DM content were found under various row spacings (Iptas \& Acar 2006) or stand densities (Millner \& Villaver 2005). Similarly, Beres et al. (2008) did not observe any effect of stand density, row spacing or their interaction on maize DM content under applied irrigation. In the present experiment, lower stand density significantly reduced DM content but this effect was visible only for narrow rows. Within the same density, row effect was not significant. It appeared that simple row spacing effect on DM content was small but could be enhanced by interaction with plant population density. However, this is also modified by environmental conditions where these changes seem to be eliminated under irrigation (Beres et al. 2008). In present experiment, significantly reduced DM content was observed at narrow rows treatment under drier end of vegetation period.

Regarding plant NDF concentration, the differences between row spacing were not significant at both sites. It is in line with Widdicombe and Thelen (2002) that the narrow row production system did not impact maize NDF content. However, some impact of row spacing in Experiment A was visible in stover NDF content, where narrow rows resulted in almost significantly higher stover NDF content. Higher difference was found at 110,000 plants/ha than at 92,000 plants/ha. Similarly, at lower stand density in Experiment B, minimal difference in stover NDF content was observed. Our 
result suggests that the effect of row spacing on NDF was higher in stover than in the whole plant. Similar tendency for whole plant NDF content was reported by Beres et al. (2008). Under various stand densities, Çarpici et al. (2010) and Marsalis et al. (2010) had not found any significant effect on plant NDF, which is in accordance with our results. However, Widdicombe and Thelen (2002) recorded an increase in NDF (from 441 to $456 \mathrm{~g} / \mathrm{kg}$ ) as the stand density increased from 64,200 to 88,900 plants/ha. Cox and Cherney (2001) found significantly higher NDF concentrations $(473 \mathrm{~g} / \mathrm{kg})$ at 116,000 plants/ha compared with 80,000 plants/ha $(460 \mathrm{~g} / \mathrm{kg})$.

Starch content in the ear was not affected by plant spacing arrangement in both the experiment sites. Contrary to this, Beres et al. (2008) reported an almost significant reduction in starch content in whole plant maize biomass under narrow rows treatment. This discrepancy could probably be explained by the changes in plant part proportions. It seems that starch content in maize biomass can be influenced by row spacing but our result shows that it is more closely connected with ear proportion than starch content in the ear.

Similar to starch, CP content in the stover was also not affected by either row spacing or stand density. It is in line with the research by Çarpici et al. (2010) and Marsalis et al. (2010) in which they reported no significant effect of stand density on $\mathrm{CP}$ content. Conversely, Widdicombe \& Thelen (2002) recorded a decrease in CP (from $76 \mathrm{~g} / \mathrm{kg}$ to $72 \mathrm{~g} / \mathrm{kg}$ ) as the stand density increased from 64,200 plants/ha to 88,900 plants/ha. Also Cox and Cherney (2001) found significantly lower $\mathrm{CP}$ concentrations at 116,000 plants $/ \mathrm{ha}(52 \mathrm{~g} / \mathrm{kg})$ compared with 80,000 plants/ha $(55 \mathrm{~g} / \mathrm{kg})$. Regarding row spacing, Skonieski et al. (2014) recorded a significantly higher content of CP (70 and $68 \mathrm{~g} / \mathrm{kg}$ ) for conventional rows $(0.60$ and $0.80 \mathrm{~m})$ compared with narrow rows $(54 \mathrm{~g} / \mathrm{kg}$ at $0.40 \mathrm{~m})$. Also, Baron et al. (2006) found marginally higher protein concentration $(74 \mathrm{~g} / \mathrm{kg})$ in comparison with narrow rows $(72 \mathrm{~g} / \mathrm{kg})$. It is, therefore, possible to conclude that the reported effects of stand density or row spacing for $\mathrm{CP}$ content could be significant; however, the differences observed by the above-cited studies were generally marginal for absolute values. The expression of these effects in CP content has also been related to site conditions (Cusicanqui \& Lauer 1999), intensity of nitrogen fertilisation (Cox \& Cherney 2001) and applied levels of stand density (Çarpici et al. 2010).

\section{CONCLUSIONS}

In the humid year 2013, a significant increase in maize yield was observed under higher stand density. The influence of row spacing effect on maize yield, morphology and quality was not meaningful at both the sites. In experiment A, plant morphology (ear ratio) and quality (stover NDF) were more affected by the interaction between row spacing and stand density than by a row spacing effect. In line with Experiment B, it seems that observed differences in these traits were smaller under low stand density. Using of narrow rows showed benefit in higher yield; however, achieved results reveal that forage quality should be also considered. It appeared that narrow rows could increase ear ratio under higher stand density but tendency for higher stover NDF content was also observed.

Acknowledgements. Supported by the Ministry of Education, Youth and Sports of the Czech Republic (S grant) and by the Grant Agency of the Faculty of Agrobiology, Food and Natural Resources, Czech University of Life Sciences Prague (Project No. SV13-46-21240).

\section{REFERENCES}

ASSOCIATION OF OFFICIAL ANALYTICAL CHEMISTS. 2005. Official methods of analysis, $18^{\text {th }}$ Ed. Gaithersburg, USA: Association of Official Analytical Chemists. AOAC International.

BAGHDADI, A. - HALIM, R.A. - MAJIDIAN, M. DAUD, W.N.W. - AHMAD, I. 2012. Plant density and tillage effects on forage corn quality. In Journal of Food Agriculture and Environment, vol. 10, no. 2, pp. 366-370.

BALKCOM, K.S. - SATTERWHITE, J.L. - ARRIAGA, F.J. - PRICE, A.J. - VAN SANTEN, E. 2011. Conventional and glyphosate-resistant maize yields across plant densities in single- and twin-row con- 
figurations. In Field Crops Research, vol. 120, no. 3, pp. 330-337. DOI: 10.1016/j.fcr.2010.10.013

BARBIERI, P. - ECHARTE, L. - DELLA MAGGIORA, A. - SADRAS, V.O. - ECHEVERRIA, H. - ANDRADE, F.H. 2012. Maize evapotranspiration and water-use efficiency in response to row spacing. In Agronomy Journal, vol. 104, no. 4, pp. 939-944. DOI: 10.2134/ agronj2012.0014

BARON, V.S. - NAJDA, H.G. - STEVENSON, F.C. 2006. Influence of population density, row spacing and hybrid on forage corn yield and nutritive value in a cool-season environment. In Canadian Journal of Plant Science, vol. 86, no. 4, pp. 1131-1138. DOI: 10.4141/P05-136

BERES, B.L. - BREMER, E. - VAN DASSELAAR, C. 2008. Response of irrigated corn silage to seeding rate and row spacing in southern Alberta. In Canadian Journal of Plant Science, vol. 88, no. 4, pp. 713-716. DOI: $10.4141 /$ CJPS 08012

ÇARPICI, E.B. - CELIK, N. - BAYRAM, G. 2010. Yield and quality of forage maize as influenced by plant density and nitrogen rate. In Tourkish Journal of Field Crops, vol. 15, no. 2, pp. 128-132.

COX, J.C. - CHERNEY, D.J.R. 2001. Row spacing, plant density, and nitrogen effects on corn silage. In Agronomy Journal, vol. 93, no. 3, pp. 597-602. DOI: 10.2134/agronj2001.933597x

CUSICANQUI, J.A. - LAUER, J.G. 1999. Plant density and hybrid influence on corn forage yield and quality. In Agronomy Journal, vol. 91, no. 6, pp. 911-915. DOI: $10.2134 /$ agronj1999.916911x

CZECH STATISTICAL OFFICE. 2015. Statistical yearbook of the Czech Republic 2015. Czech Statistical Office. 799 pp. ISBN 978-80-250-2638-0.

GÖZÜBENLI, H. 2010. Influence of planting patterns and plant density on the performance of maize hybrids in the eastern Mediterranean conditions. In International Journal of Agriculture and Biology, vol. 12 , no. 4, pp. 556-560.

GÖZÜBENLI, H. - KILINC, M. - SENER, O. - KONUSKAN, O. 2004. Effects of single and twin row planting on yield and yield components in maize. In Asian Journal of Plant Sciences, vol. 3, no. 2, pp. 203-206.

IPTAS, S. - ACAR, A.A. 2006. Effects of hybrid and row spacing on maize forage yield and quality. In Plant, Soil and Environment, vol. 52, no. 11, pp. 515-552.

IUSS Working Group WRB. 2014. World Reference Base for Soil Resources 2014. International soil classification system for naming soils and creating legends for soil maps. World Soil Resources No. 106. FAO, Rome.

LYNCH, J.P. - O'KIELY, P. - DOYLE, E.M. 2012. Yield, quality, and ensilage characteristics of whole-crop maize and of the cob and stover components: harvest date and hybrid effects. In Grass and Forage Science, vol. 67 , no. 4 , pp. 472-487. DOI: $10.1111 / \mathrm{j} .1365-$ 2494.2012.00868.x

MAQBOOL, M.M. - TANVEER, A. - ATA, Z. - AHMAD, R. 2006. Growth and yield of maize (Zea mays L.) as affected by row spacing and weed competition durations. In Pakistan Journal of Botany, vol. 38, no. 4, pp. 1227-1236.
MARSALIS, M.A. - ANGADI, S.V. - CONTRERAS-GOVEA, F.E. 2010. Dry matter yield and nutritive value of corn, forage sorghum, and BMR forage sorghum at different plant populations and nitrogen rates. In Field Crops Research, vol. 116, no. 1-2, pp. 52-57. DOI: 10.1016/j.fcr.2009.11.009

MILLNER, J.P. - VILLAVER, R. 2005. The yield and nutritive value of maize hybrids grown for silage. In New Zealand Journal of Agricultural Research, vol. 48, no. 1, pp. 101-108. DOI: $10.1080 / 00288233.2005 .9513637$

MOdolo, A.J. - CARNiElETto, R. - KOlling, E.M. - Trogello, E. - SGARbossA, M. 2010. Performance of corn hybrids at the Southwest of Parana under different row spacing. In Revista Ciencia Agronomica, vol. 41, no. 3, pp. 435-441. DOI: http:// dx.doi.org/10.1590/S1806-66902010000300016

NOVACEK, M.J. - MASON, S.C. - GALUSHA, T.D. -YASEEN, M. 2013. Twin rows minimally impact irrigated maize yield, morphology, and lodging. In Agronomy Journal, vol. 105, no. 1, pp. 268-276. DOI: 10.2134/agronj2012.0301

RAMEZANI, M. - ABANDANI, S.R.R. - MOBASSER, H.R. - AMIRI, E. 2011. Effects of row spacing and plant density on silage yield of corn (Zea mays L. cv. sc 704) in two plant pattern in North of Iran. In African Journal of Agricultural Research, vol. 6, no. 5, pp. 1128-1133. DOI: 10.5897/AJAR10.898

ROBLES, M. - CIAMPITTI, I.A. - VYN, T.J. 2012. Responses of maize hybrids to twin-row spatial arrangement at multiple plant densities. In Agronomy Journal, vol. 104, no. 6, pp. 1747-1756. DOI: 10.2134/ agronj2012.0231

SKONIESKI, F.R. - NÖRNBERG, J.L. - KESSLER, J.D. - DE DAVID, D.B. - DE AZEVEDO, E.B. BRÜNING, G. - PIMENTEL, C.M.M. 2014. Corn plant arrangement and its effect on silage quality. In Revista Brasileira de Zootecnia, vol. 43, no. 3, pp. 114-119. DOI: http://dx.doi.org/10.1590/S151635982014000300002

STATISTICA, version 12. 2013. Data analysis software system, StatSoft Inc., Tulsa, USA.

STONE, P. - PEARSON, A. - SORENSEN, I. - ROGERS. B. 2000. Effect of row spacing and plant population on maize yield and quality. In $30^{\text {th }}$ Joint NZIAS/NZSHS Annual Conference, Proceedings of the Agronomy Society of New Zeland, vol. 30, pp. 67-75.

STRIEDER, M.L. - da SILVA, P.R.F. - RAMBO, L. SANGOI, L. - da SILVA, A.A. - ENDRIGO, P.C. JANDREY, D.B. 2008. Crop management systems and maize grain yield under narrow row spacing. In Scientia Agricola, vol. 65, no. 4, pp. 346-353. DOI: http:// dx.doi.org/10.1590/S0103-90162008000400004

ter BRAAK, C.J.F. - ŠMILAUER, P. 2002. CANOCO Reference Manual and CanoDraw for Windows User's Guide: Software for Canonical Community Ordination (Version 4.5). Microcomputer Power, Ithaca, USA.

TURGUT, I. - DUMAN, A. - BILGILI, U. - ACIKGOZ, E. 2005. Alternate row spacing and plant density effects on forage and dry matter yield of corn hybrids (Zea 
mays L.). In Journal Agronomy and Crop Science, vol. 191, no. 2, pp. 146-141. DOI: 10.1111/j.1439037X.2004.00146.X

WIDDICOMBE, W.D. - THELEN, K.D. 2002. Row width and plant density effect on corn forage hybrids. In Agronomy Journal, vol. 94, no. 2, pp. 326-330. DOI: 10.2134/agronj2002.3260
ZAMIR, M.S.I. - AHMAD, A.H. - JAVEED, H.M.R. LATIF, T. 2011. Growth and yield behaviour of two maize hybrids (Zea mays L.) towards different plant spacing. In Cercetări Agronomice în Moldova, vol. 44 , no. 2 , pp. 33-40.

Received: May 30, 2016 